\title{
Chemical composition of wet precipitation of air pollutants: A case study in Karachi, Pakistan
}

\author{
MUHAMMAD NASIRUDDIN KHAN \\ Department of Chemistry, University of Karachi, Karachi-75270, Pakistan \\ Corresponding author; e-mail: nasiruk@uok.edu.pk
}

ANILA SARWAR

Fuel Research Centre, Pakistan Council of Scientific and Industrial Research, Karachi-75280, Pakistan

Received January 31, 2013; accepted October 14, 2013

\begin{abstract}
RESUMEN
La contaminación atmosférica se ha considerado como uno de los desafíos ambientales más importantes a causa de su impacto directo en los ecosistemas y la salud humana. Se monitorearon los cambios temporales en la composición de 20 muestras de agua de lluvia en la región árida de Karachi, Pakistán, durante el monzón del suroeste de 2009, para evaluar de forma indirecta la calidad del aire. El objetivo del estudio fue identificar los niveles de la contaminación atmosférica y su posible componente antropogénico. Se analizaron los iones de metales con el fin de predecir riesgos para la salud. Se encontró que las muestras de lluvia fueron alcalinas ( $\mathrm{pH}$ 5.55-7.55) debido a la presencia de partículas ricas en calcio y magnesio. Las lluvias continuas en días consecutivos mostraron un descenso notable en los niveles de contaminación, en tanto que la estación seca los potenció. Se observaron correlaciones importantes del total de sólidos disueltos con $\mathrm{K}^{+}$, $\mathrm{Na}^{+}, \mathrm{Ca}^{2+}, \mathrm{Mg}^{2+} \mathrm{y} \mathrm{Cl}^{-}$, así como una correlación relativamente débil del total de partículas suspendidas con los metales, lo que sugiere la presencia de otras partículas suspendidas en el aire. Se utilizaron análisis de componentes principales y de medias para predecir fuentes antropogénicas de contaminación. Este estudio será útil para definir la planeación estratégica y formular políticas orientadas a controlar los niveles de contaminación atmosférica en la ciudad.
\end{abstract}

\begin{abstract}
Air pollution has been considered one of the most important environmental challenges because of its direct effect on ecosystems and human health. Temporal changes in the composition of 20 samples of rainwater in the arid region of Karachi, Pakistan during the southwest monsoon of 2009 have been monitored to carry out the indirect assessment of air quality. The study has been fulfilled with the aim of identifying the level of air pollution, and the relative contribution of possible anthropogenic activities. Metal ions were analyzed to predict health risks. Rain samples were found to be alkaline ( $\mathrm{pH}$ 5.55-7.55) due to the influence of calcium and magnesium rich particles. Continuous rains in consecutive days showed a remarkable decline in air pollution while the dry season boosted up the level of pollution. Strong correlations of total dissolved solids with $\mathrm{K}^{+}, \mathrm{Na}^{+}, \mathrm{Ca}^{2+}, \mathrm{Mg}^{2+}$, and $\mathrm{Cl}^{-}$were observed. A relatively weak correlation of total suspended particles with metals showed the possibility of some other particulate matters being suspended in the air. Principal component analysis and analysis of means were used to predict the anthropogenic source of pollution. This study will be helpful to formulate strategic planning and policies for controlling the level of air pollution in the city.
\end{abstract}

Keywords: Karachi, air pollution, rainwater, chemical composition, multivariate analysis. 


\section{Introduction}

Pollution monitoring through the estimation of air pollutants in wet deposition has increased during the last decades (Zapletal et al., 2007; Holder, 2004). Fog in the metropolitan area of Karachi occurs during the winter season (November to March). The southwest monsoon arises during the summer from June to September throughout Pakistan, excluding the regions of western Balochistan, Chitral, Gilgit-Baltistan, and the Federally Administered Tribal Areas. Monsoon rains bring a much-awaited relief from the scorching summer heat. These monsoon rains are quite heavy by nature and can cause significant flooding.

The monsoon regime dominates the climate of Pakistan. Karachi is the biggest and largest industrial city of the country, heavily populated with 18 million inhabitants in an area of $3527 \mathrm{~km}^{2}$ and an elevation of $8 \mathrm{~m}$. It has an arid climate with a low average precipitation level (approximately $250 \mathrm{~mm}$ per annum), most of which occurs during July-August or in September as a late monsoon season. Located on the coast, pollutants are pushed towards the shore during the north-east (NE) monsoon and inland during the south-west (SW) monsoon (Ghauri and Mirza, 1994). Depending upon the nature of air pollutants, rainwater may be acid or alkaline. Industries and vehicles emit a large amount of $\mathrm{NO}_{\mathrm{x}}$ and $\mathrm{SO}_{2}$, which are responsible for acid rain. Acid rain reflects the emission of acidic gases as the result of anthropogenic activities (Ham et al., 2010). $\mathrm{NO}_{\mathrm{x}}$ and $\mathrm{SO}_{2}$ are transformed to $\mathrm{HNO}_{3}$ and $\mathrm{H}_{2} \mathrm{SO}_{4}$ when they interact with water in the atmosphere. The acids combine with moisture in the air and fall to the earth as acid rain or snow. Conversely, dust particles may contain a significant amount of basic cations which neutralize the acidity of rainwater. The composition of rainwater plays an important role in attracting pollutants from the atmosphere. Particulate matter plays an important role in attracting metal pollutants (Mohiuddin et al., 2010). The scavenged metals can deposit to the air up to a distance of $100 \mathrm{~km}$ from their source. Therefore, the estimation of anions in acidic rain and cations in alkaline rain is of great importance for source identification of air pollution in rainwater.

Considering the importance of rainwater chemistry, the present study has been carried out with the aim of identifying the variations in the amount of ionic species during one monsoon season (com- prising 13 events) and the contribution of possible anthropogenic activities in the studied areas. The data obtained in this study significantly contribute to the limited knowledge of temporal variations of rainwater quality in Karachi, in order to understand its use as an alternative to drinking water, especially in areas of short domestic water supply. The study can also increase the awareness of common people towards an important environmental issue. Data are compared by means of statistical analysis with similar works carried out at various regions of the world.

\section{Materials and methods}

\subsection{Sampling sites}

Karachi is located in southern Pakistan $\left(24^{\circ} 48^{\prime} \mathrm{N}\right.$, $66^{\circ} 59^{\prime}$ E) at the coast of the Arabian Sea (Indian Ocean); as a result, it has a relatively mild arid climate. Being the industrial hub of the country, most industries (including textiles, chemicals and fertilizers, food processing, building materials, petroleum refining, and ship repairing) are located in this region. According to a report of air quality management in Karachi, $\mathrm{NO}_{\mathrm{x}}$ and $\mathrm{SO}_{2}$ levels range from 10 to 43.70 and 7.90 to $21.90 \mu \mathrm{g} / \mathrm{m}^{3}$, respectively (Institutional Analysis of Air Quality Management in Urban Pakistan, 2009). Moreover, the city is rapidly affected by the increase in industrialization, energy consumption, dust emitted from vast construction activities and dry sand storms. For these reasons, significant deterioration on air quality has occurred, causing accumulation of pollutants on trees, land, and air. These pollutants reach ground through precipitation (Wahid et al., 2001) and were subjected to analysis for the assessment.

The Pakistan Meteorological Department recorded pre-monsoon activity in Karachi on June 23 and 25,2009 due to the formation of a weak tropical depression in the Arabian Sea. As a result of this depression, the storm caused monsoon rainfall on June 26. It was a light shower with gusty winds (11 $\mathrm{km} / \mathrm{h}$ ) in the coastal area. The next heavy shower was witnessed from July 18 in Karachi. It was the second highest precipitation in the history of Karachi ( $245 \mathrm{~mm}$ in four hours), and caused severe flooding in the city. This record-breaking rainfall in Karachi developed first as a tropical depression in the Bay of Bengal and moved in a west-north-west direction; it hit Karachi after crossing Madhya Pradesh and Rajasthan, in India. The second monsoon system 


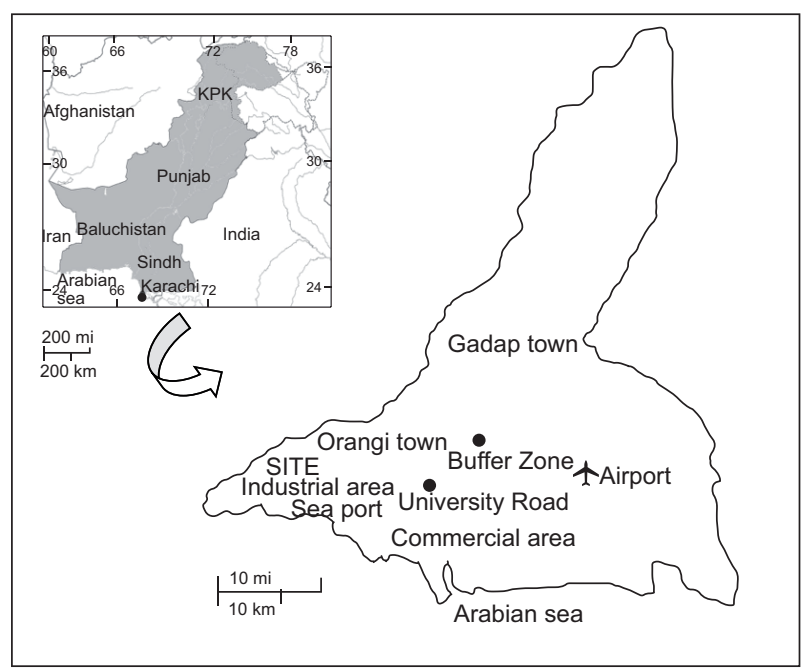

Fig. 1. Sampling sites in the metropolitan area.

developed over the northwest Bay of Bengal; then it intensified into a tropical depression and moved in the same direction as the previous one. After crossing the southern part of Rajasthan it moved towards Karachi, where it dissipated. This system caused moderate isolated rain $(18 \mathrm{~mm})$ on July 20 with strong winds in Karachi. Twenty samples of rainwater were collected from the two residential areas of the city: nine from the University Road (UR) and 11 from the Buffer Zone (BZ) during the 2009 SW monsoon season (June to July). Figure 1 shows the location of the sampling sites.

The UR sampling site is located $15 \mathrm{~km}$ from the center of the city $\left(24^{\circ} 56^{\prime} 18.79^{\prime \prime} \mathrm{N}, 67^{\circ} 7^{\prime} 13.02^{\prime \prime} \mathrm{E}\right)$. Vehicular traffic and domestic heating appear to be the most important local emission sources. The BZ site $\left(24^{\circ} 57^{\prime} 24^{\prime \prime} \mathrm{N}, 67^{\circ} 3^{\prime} 48^{\prime \prime} \mathrm{E}\right)$ is located $7 \mathrm{~km}$ from the center, adjacent to cement worka and the hilly area of Orangi town. During 2008-2009, a number of construction activities have been carried out in this area by the government of the Karachi district. Other specific pollution sources were vehicular traffic and domestic heating.

Sampling was carried out in a total deposition sampler (Fig. 2) mounted approximately $3 \mathrm{~m}$ above the ground level, away from surface soil and any specific contamination source (Hameed et al., 2006).

Rainwater falls into a polyethene funnel and fills the sample bottle of $500 \mathrm{ml}$ through a tube. The overflow of the sample bottle falls into a second bottle, which is already filled with water. A tube is connected to the second bottle for pouring out

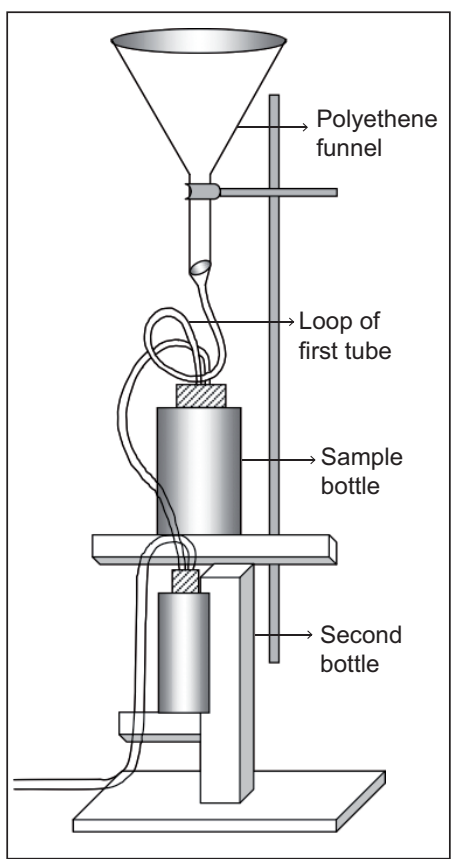

Fig. 2. Sample collector.

superfluous water to the ground. The second bottle provides humid air in the tube and eliminates the risk of sample evaporation from the bottle. The loop of the first tube is helpful to maintain the original ion concentration by trapping water and preventing evaporation.

Precipitation samples were collected during the first few minutes of each event, when the highest concentration of pollutants is present (Tuncel et al., 1994; Dupre et al., 2006). In case of continuous rain, consecutive samples of the same event were collected every $6 \mathrm{~h}$. The samples were analyzed for alkalinity, $\mathrm{pH}$ and conductivity within $24-48 \mathrm{~h}$. The rest of the samples were stored at $4{ }^{\circ} \mathrm{C}$ to minimize physicochemical changes. The analysis was completed within one week of sample collection.

\subsection{Methods}

Different analytical techniques were used to determine the composition of precipitation. $\mathrm{A} \mathrm{pH}$ meter (Orion $520 \mathrm{~A}$ ) was used to measure the $\mathrm{pH}$ of rain samples. Sodium $(\mathrm{Na})$, potassium $(\mathrm{K})$, calcium $(\mathrm{Ca})$ and magnesium $(\mathrm{Mg})$ were quantified using the atomic absorption spectrophotometer PE-2380. The Orion 960 Autochemistry system was used to measure chloride $\left(\mathrm{Cl}^{-}\right)$in the samples. $\mathrm{NH}_{4}^{+}, \mathrm{NO}_{3}{ }^{-}, \mathrm{SO}_{4}{ }^{2-}$, and alkalinity were measured in accordance with the standard 
Table I. Detection limits of measured $\mathrm{pH}$ and ions.

\begin{tabular}{cc}
\hline Parameter & Detection limits \\
\hline $\mathrm{pH}$ & 0.05 \\
$\mathrm{NH}_{4}^{+}$ & $0.03 \mathrm{mg} / \mathrm{L}$ \\
$\mathrm{Na}^{+}$ & $0.1 \mathrm{mg} / \mathrm{L}$ \\
$\mathrm{K}^{+}$ & $0.1 \mathrm{mg} / \mathrm{L}$ \\
$\mathrm{Ca}^{2+}$ & $0.1 \mathrm{mg} / \mathrm{L}$ \\
$\mathrm{Mg}^{2+}$ & $0.1 \mathrm{mg} / \mathrm{L}$ \\
$\mathrm{Cl}^{-}$ & $0.1 \mathrm{mg} / \mathrm{L}$ \\
$\mathrm{NO}_{3}^{-}$ & $0.1 \mathrm{mg} / \mathrm{L}$ \\
$\mathrm{SO}_{4}{ }^{2-}$ & $1.0 \mathrm{mg} / \mathrm{L}$ \\
\hline
\end{tabular}

methods for examination of water and waste water APHA, AWWA and WEF, 1992). The detection limits of measured $\mathrm{pH}$ and ions are shown in Table I. Total dissolved solids (TDS) and conductivity were measured with a Jenway 4320 conductivity meter. Total suspended particles (TSP) were measured by filtering $100 \mathrm{ml}$ of rainwater through a pre-weighed high-efficiency glass-microfiber filter (Whatman GF/F) that was dried to constant weight at $60^{\circ} \mathrm{C}$. The calculation was made using the following equation:

$\operatorname{TSP}(\mathrm{mg} / \mathrm{L})=([\mathrm{A}-\mathrm{B}] \times 1000) / \mathrm{C}$

where A is the final dried weight of the filter in $\mathrm{g}$, $\mathrm{B}$ is the initial weight of the filter in $\mathrm{g}$ and $\mathrm{C}$ is the volume of water filtered measured in liters. The concentration of $\mathrm{HCO}_{3}{ }^{-}$was estimated from the theoretical relationship described by Kulshrestha et al. (2003):

$$
\left[\mathrm{HCO}_{3}^{-}\right]=10^{(\mathrm{pH}-5.05)} \mu \mathrm{eq} / \mathrm{L}
$$

Chemometric measurements were performed using the statistical software Minitab version 14.

\subsection{Quality control}

To ensure the accuracy and reproducibility of data we used analytical grade reagents, as well as class "A" volumetric glassware. The standards for atomic absorption spectrophotometry were those of May \& Baker, Ltd., England. Standard reference materials Spectroquant CombiCheck 30 and 40 (Darmstadt, Germany) were used as quality control samples.

\section{Results and discussion}

\subsection{Chemical composition}

The chemical composition of UR and BZ rain samples are summarized in Tables II and III. Rainwater $\mathrm{pH}$ has been considered the most important parameter to predict the nature of anthropogenic activities.

The $\mathrm{pH}$ value generally assumed as neutral for rainwater is 5.6. It is the $\mathrm{pH}$ of cloud water at equilibrium with atmospheric $\mathrm{CO}_{2}$ (Wang and Han, 2011). The majority of samples showed a $\mathrm{pH}$ substantially higher than the neutral value. It was ranged from 5.55-6.10 with a mean value of 5.81 for UR and 6.52-8.09 with a mean value of 7.16 for BZ samples.

Figure 3 shows the sample distribution for $\mathrm{pH}$ at both sampling stations. Out of nine rain events at UR, only two were observed in a neutral range, which occurred after continuous rain. At BZ, $\mathrm{pH}$ was

Table II. Chemical composition of rainwater samples.

\begin{tabular}{|c|c|c|c|c|c|c|c|c|c|c|c|c|}
\hline \multirow[t]{2}{*}{ Date } & \multirow{2}{*}{$\begin{array}{l}\text { Amount of } \\
\text { rain } \\
(\mathrm{mm})\end{array}$} & \multirow{2}{*}{$\begin{array}{c}\text { Sampling } \\
\text { time } \\
\text { (LT) }\end{array}$} & \multicolumn{2}{|c|}{$\begin{array}{l}\text { Alkalinity } \\
\text { (mg/L) }\end{array}$} & \multicolumn{2}{|c|}{$\begin{array}{l}\text { Conductivity } \\
(\mu \mathrm{S} / \mathrm{cm})\end{array}$} & \multicolumn{2}{|c|}{$\begin{array}{c}\mathrm{TDS} \\
(\mathrm{mg} / \mathrm{L})\end{array}$} & \multicolumn{2}{|c|}{$\begin{array}{c}\text { TSP } \\
(\mathrm{mg} / \mathrm{L})\end{array}$} & \multicolumn{2}{|c|}{$\mathrm{pH}$} \\
\hline & & & UR & $\mathrm{BZ}$ & UR & BZ & UR & BZ & UR & BZ & UR & BZ \\
\hline 26-Jun & 2.5 & $16: 05$ & 46 & 86 & 303.0 & 238.0 & 182.3 & 142.6 & 40 & 86 & 6.10 & 6.74 \\
\hline 18-Jul & 2.5 & $5: 55$ & 32 & 24 & 97.8 & 200.0 & 58.7 & 120.0 & 8 & 24 & 5.74 & 7.23 \\
\hline 18-Jul & & $11: 30$ & 18 & - & 22.2 & - & 13.3 & - & 4 & - & 5.55 & - \\
\hline 18-Jul & & $17: 55$ & 10 & - & 4.3 & - & 2.6 & - & 0 & - & 5.93 & - \\
\hline 19-Jul & 2.5 & $12: 30$ & 26 & 48 & 43.6 & 45.3 & 25.8 & 27.2 & 64 & 48 & 5.82 & 6.71 \\
\hline 19-Jul & & $18: 40$ & 24 & 24 & 68.1 & 42.5 & 40.9 & 25.5 & 8 & 24 & 5.82 & 6.94 \\
\hline 22-Jul & 2.4 & $7: 55$ & 32 & 110 & 102.1 & 866.0 & 61.3 & 520.0 & 80 & 110 & 5.70 & 8.09 \\
\hline 22-Jul & & $14: 30$ & 48 & 50 & 54.7 & 241.0 & 32.8 & 144.6 & 0 & 50 & 5.58 & 7.40 \\
\hline 23-Jul & 2.4 & $8: 25$ & 36 & 52 & 95.8 & 146.8 & 57.5 & 88.1 & 32 & 52 & 6.08 & 7.54 \\
\hline 24-Jul & 2.4 & $12: 30$ & - & 64 & - & 218.0 & - & 131.0 & - & 64 & - & 7.55 \\
\hline 30-Jul & 2.2 & $6: 25$ & - & 24 & - & 30.6 & - & 18.4 & - & 24 & - & 6.87 \\
\hline 30-Jul & & $21: 20$ & - & 32 & - & 51.8 & - & 31.1 & - & 32 & - & 7.20 \\
\hline 31-Jul & 2.2 & $12: 50$ & - & 24 & - & 23.0 & - & 13.8 & - & 24 & - & 6.52 \\
\hline
\end{tabular}




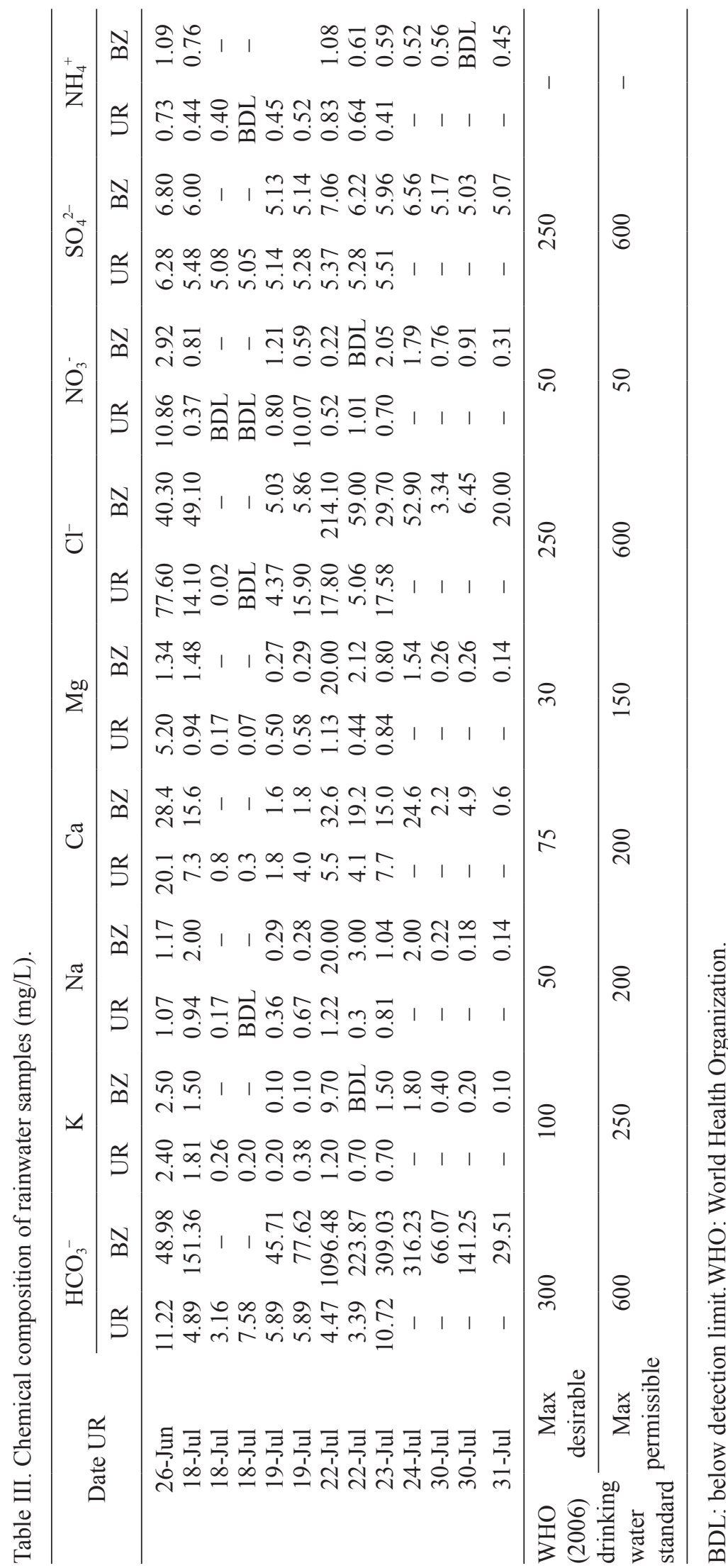




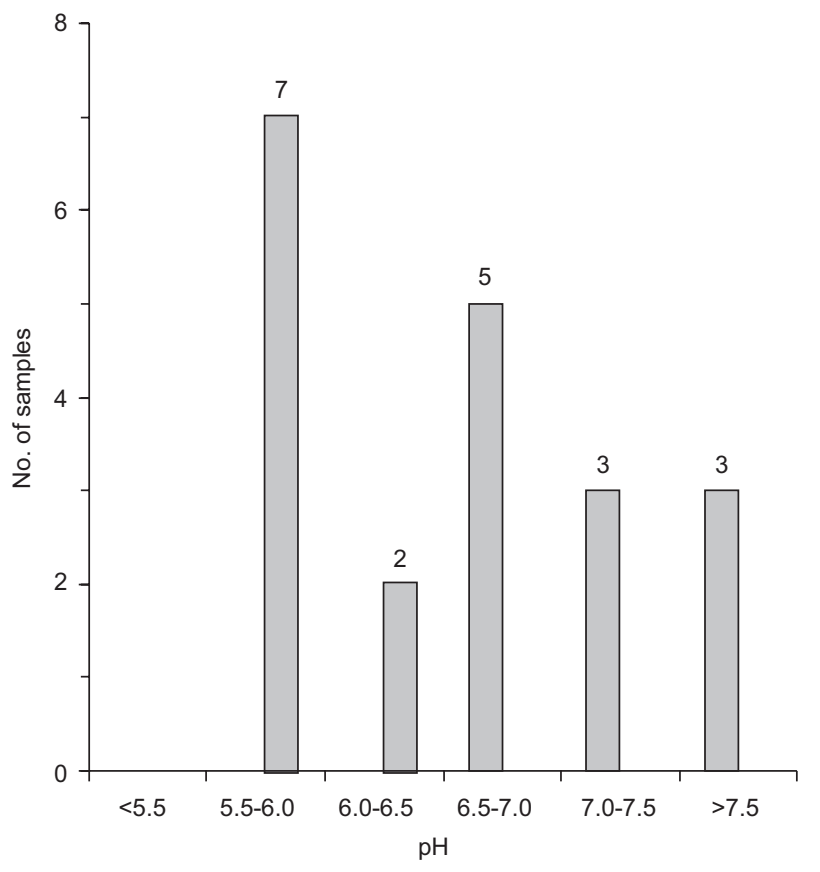

Fig. 3. Samples distribution for $\mathrm{pH}$.

persistently alkaline $(>5.6)$ in all events. Alkaline $\mathrm{pH}$ suggested that the influence of anthropogenic sources due to acidic gases is minor and the effect of particulate matters of alkaline nature like dust particles is dominant. This showed similarity to data obtained from some Indian sites, Lucknow (Khare et al., 2004), Gopalpura, Agra (Satsangi et al.,1998), and Bhubaneswar (Das et al., 2005).

Alkalinity was measured as 10-48 and 24-110 $\mathrm{mg} / \mathrm{L}$ of $\mathrm{CaCO}_{3}$ for $\mathrm{UR}$ and $\mathrm{BZ}$ samples, respectively. The alkalinity of rainwater does not mean that rain has an acidic or alkaline nature; it measures the buffering capacity of the samples due to varying amounts of $\mathrm{OH}^{-}, \mathrm{CO}_{3}{ }^{2-}$, and $\mathrm{HCO}_{3}^{-}$. UR samples may be considered too clean with a mild buffering capacity (alkalinity $<50 \mathrm{mg} / \mathrm{L}$ ). The results are comparable with the study of Huo et al. (2011). BZ samples showed relatively higher alkalinity, especially at the starting of the first and second monsoon system. This observation is associated with high loading of abundant particulate matters (especially dust) in the atmosphere as a result of ongoing construction activities. It is important to note that the first and second monsoon systems caused rainfall with strong and gusty winds in Karachi. Therefore, wind also contributed to the transportation of fine dust from the mountains of Orangi town, a neighboring area of BZ. This assumption is supported by the amounts of TSP in rainstorms of BZ (Table II). Consequently, it was concluded that the air of BZ is significantly contaminated with base cations or alkaline aerosols which neutralized the acidity of rainwater before being deposited on the ground surface (Kulshrestha et al., 2003). Continuous rain events on July 18, 2009, settled down the alkaline aerosols onto the earth and dropped the alkalinity values of UR and BZ samples from 46-84 to 10$12 \mathrm{mg} / \mathrm{L}$, respectively. This resulted in values of alkalinity of rainwater comparable to those of fresh water $(20-200 \mathrm{mg} / \mathrm{L})$.

The electrical conductivity of rainwater ranges from $4.32-303 \mu \mathrm{S} \mathrm{cm}^{-1}$ in UR samples and $23-866 \mu \mathrm{S} \mathrm{cm}^{-1}$ in BZ samples. Consecutive rains at UR $(\sim 200 \mathrm{~mm})$ made conductivity very close to deionized water $(0.5$ $\left.3.0 \mu \mathrm{S} \mathrm{cm}^{-1}\right)$. The highest value of conductivity was observed on July 22 for a BZ sample. It is evident from Table III that the highest amounts of $\mathrm{Cl}^{-}, \mathrm{HCO}_{3}^{-}$, $\mathrm{Na}^{+}, \mathrm{K}^{+}, \mathrm{Ca}^{2+}$, and $\mathrm{Mg}^{2+}$ were also observed in the same sample. Therefore, the highest conductivity was attributed to the strong contribution of dissolved salts of these ions.

The values of $\mathrm{Cl}^{-}$in water samples were within those defined by the World Health Organization in its guidelines for drinking-water quality (WHO, 2006). Versari et al. (2002) concluded that a $\mathrm{Cl}^{-}$concentration higher than $250 \mathrm{mg} / \mathrm{L}$ is responsible for an unpleasant taste of water and represents a risk to human health. It is evident from Table III that only one sample collected on July 22 at BZ shows a value as high as $214 \mathrm{mg} / \mathrm{L} \mathrm{Cl}^{-}$. The possible sources of $\mathrm{Cl}^{-}$in rainwater are marine aerosols, and industrial or vehicular emission. A higher amount of $\mathrm{Na}$ in the same sample represents a high electrolyte $(\mathrm{NaCl})$ concentration in rain due to marine aerosols.

$\mathrm{SO}_{4}{ }^{2-}$ ions were measured as 5.05-6.80 and 5.03$7.06 \mathrm{mg} / \mathrm{L}$ in UR and BZ samples, respectively. These values are in good agreement with the data reported by Zapletal et al. (2007). $\mathrm{NO}_{3}{ }^{-}$was estimated as $<0.1-10.86$ and $<0.1-2.92 \mathrm{mg} / \mathrm{L}$ in UR and BZ samples. $\mathrm{NH}_{4}{ }^{+}$ions were estimated up to 0.83 and $1.09 \mathrm{mg} / \mathrm{L}$ in UR and BZ samples, respectively. The higher amount of $\mathrm{NO}_{3}{ }^{-}$and lower amount of $\mathrm{NH}_{4}{ }^{+}$ in UR samples shows the contribution of industrial activities in the region. High amounts of suspended particulate matter were found in BZ samples, which were rich in dust particles and $\mathrm{Ca}$ and $\mathrm{Mg}$ salts. TSP buffers the acidity of rain samples below the cloud 
Table IV. Comparison of the relative magnitude of ionic species with other sites

\begin{tabular}{lll}
\hline Sites & Order of ionic species & Reference \\
\hline Karachi, Pakistan & $\mathrm{HCO}_{3}^{-}>\mathrm{Cl}^{-}>\mathrm{Ca}^{2+}>\mathrm{K}^{+}>\mathrm{Mg}^{2+}>\mathrm{Na}^{+}>\mathrm{NH}_{4}^{+}$ & This study \\
Roorkee, India & $\mathrm{Ca}^{2+}>\mathrm{HCO}_{3}^{-}>\mathrm{Cl}^{-}>\mathrm{Na}^{+}>\mathrm{Mg}^{2+}>\mathrm{K}$ & Hameed et al., 2006 \\
Agra, India & $\mathrm{Ca}^{2+}>\mathrm{Cl}^{-}>\mathrm{Na}^{+}>\mathrm{HCO}_{3}^{-}>\mathrm{K}^{+}>\mathrm{Mg}^{2+}$ & Satsangi et al., 1998 \\
Hyderabad, India & $\mathrm{Ca}^{2+}>\mathrm{Cl}^{-}>\mathrm{Na}^{+}>\mathrm{HCO}_{3}^{-}>\mathrm{K}^{+}>\mathrm{Mg}^{2+}$ & Kulshrestha et al., 2003 \\
Chembur, India & $\mathrm{Na}^{+}>\mathrm{Cl}^{-}>\mathrm{Ca}^{2+}>\mathrm{Mg}^{2+}>\mathrm{K}^{+}$ & Khemani et al., 1994 \\
Dhaka, Bangladesh & $\mathrm{Na}^{+}>\mathrm{Ca}^{2+}>\mathrm{K}^{+}>\mathrm{Mg}^{2+}>\mathrm{Cl}^{-}$ & Hadi et al., 1999 \\
Riadh, Saudi Arabia & $\mathrm{Ca}^{2+}>\mathrm{Cl}^{-}>\mathrm{Na}^{+}>\mathrm{HCO}_{3}^{-}>\mathrm{K}^{+}>\mathrm{Mg}^{2+}$ & Alabdula'aly et al., 2000 \\
Monterrey, Mexico & $\mathrm{Ca}^{2+}>\mathrm{Na}^{+}>\mathrm{Mg}^{2+}>\mathrm{NH}_{4}^{+}>\mathrm{K}^{+}>\mathrm{Cl}^{-}$ & Ramírez et al., 2010 \\
\hline
\end{tabular}

scavenging process (Hameed et al., 2006). Since the effects of industrial activities and fossil fuel burning (alkaline $\mathrm{pH}$ ) appeared to be insignificant in the studied areas, soil dust, construction materials, demolition debris, and sea salts were considered as the major natural and anthropogenic contributors to TSP (Wroble et al., 2000). It was observed that the amounts of particulates suspended in the air decreased after consecutive rains. This indicates that high rainfall washed off TSP and suppressed the lifting of dust particles; as a result, concentrations of $\mathrm{Ca}$ and $\mathrm{Mg}$ decreased.

Metal particulates play a major role in establishing the alkalinity and TDS of rain samples. The concentration of ions in rain samples of both stations followed the pattern $\mathrm{HCO}_{3}^{-}>\mathrm{Cl}^{-}>\mathrm{Ca}^{2+}>\mathrm{K}^{+}>\mathrm{Mg}^{2+}$ $>\mathrm{Na}^{+}$, indicating that $\mathrm{Ca}^{2+}$ and $\mathrm{HCO}_{3}^{-}$are the dominant cation and anion, respectively. Soil and roadside dust are the main anthropogenic sources of $\mathrm{Ca}$ and $\mathrm{Mg}$, which pollute the air by convection processes, vehicle emissions or wind (Wang and Han, 2011). The results we obtained for metal ions are in good agreement with previous studies (Huang et al., 2008; $\mathrm{Xu}$ et al., 2009).

The values of $\mathrm{Na}, \mathrm{K}, \mathrm{Ca}$, and $\mathrm{Mg}$ were found to be within the permissible levels of these elements in drinking water (WHO, 2006). The samples were also analyzed for trace metals. The concentrations of $\mathrm{Cu}, \mathrm{Fe}, \mathrm{Pb}, \mathrm{Cd}, \mathrm{Ni}, \mathrm{Cr}, \mathrm{As}, \mathrm{Hg}$ and $\mathrm{Zn}$ were below the detection limits $(2.0 \mathrm{mg} / \mathrm{L}$ for $\mathrm{As}$ and $\mathrm{Hg}$, and $0.1 \mathrm{mg} / \mathrm{L}$ for the remaining metals). Based on the analysis of the samples and their chemical composition, it is suggested that rainwater of the studied areas may be used for drinking after continuous rain of about $200 \mathrm{~mm}$.

The relative magnitude of ionic species found in rain samples on the studied areas was compared with ionic species of different origins (Table IV). In all the studies (including the present one), $\mathrm{Ca}^{2+}$ shows the highest concentration due to crustal origin, except for the precipitation in Chembur and Dhaka (Khemani et al., 1994), where the dominance of $\mathrm{Na}^{+}$and $\mathrm{Cl}^{-}$was attributed to the proximity of the ocean.

\subsection{Statistical analysis}

\subsubsection{Correlation analysis}

An excellent correlation was observed between TDS and $\mathrm{Cl}^{-}$with the determination coefficient $\mathrm{r}^{2}$ $=0.992$, and $p<0.001$. Strong correlations of TDS were also observed with $\mathrm{K}\left(\mathrm{r}^{2}=0.951, \mathrm{p}<0.001\right)$, Na $\left(\mathrm{r}^{2}=0.940, \mathrm{p}<0.001\right), \mathrm{Ca}\left(\mathrm{r}^{2}=0.834, \mathrm{p}<0.001\right)$ and $\mathrm{Mg}\left(\mathrm{r}^{2}=0.959, \mathrm{p}<0.001\right)$ (Table $\left.\mathrm{V}\right)$. This results indicate that rainwater mainly dissolves the chlorides of $\mathrm{Na}, \mathrm{K}, \mathrm{Ca}$ and $\mathrm{Mg}$. A relatively weak correlation was observed between TSP and $\mathrm{K}\left(\mathrm{r}^{2}=0.633\right)$, Na $\left(r^{2}=0.606\right), \mathrm{Ca}\left(r^{2}=0.693\right)$ and $\mathrm{Mg}\left(r^{2}=0.594\right)$, showing the possible presence of other particulate matters (dust, smoke, soot, etc.) in the atmospheric air. Alkalinity is strongly correlated with all parameters due to the high loading of particulate matter in the atmosphere, either in dissolved or suspended form. Inter-metal correlations were also estimated between $\mathrm{K}-\mathrm{Na}(0.938), \mathrm{K}-\mathrm{Mg}(0.956)$, and $\mathrm{Na}-\mathrm{Mg}$ (0.975).

\subsubsection{Multivariate analysis}

A principal component analysis (PCA) was applied to the chemical composition of studied samples and of those reported in some other regions of the world (Fig. 4). Table VI shows the values of the parameters on which the PCA was applied.

The numbers of significant principal components were selected on the basis of an eigenvalue $>1$ (Kaiser, 1960). The first principal component (PC-1) explained $67.7 \%$ of the total variability, and was predominantly a function of $\mathrm{Na}^{+}, \mathrm{K}^{+}, \mathrm{Mg}^{2+}, \mathrm{Cl}^{-}$, 
Table V. Correlations matrix between different studied parameters ( $p$-value is shown below the Pearson correlation coefficient value).

\begin{tabular}{|c|c|c|c|c|c|c|c|c|c|c|}
\hline & $\mathrm{pH}$ & Alkalinity & Conductance & TDS & $\mathrm{K}$ & $\mathrm{Na}$ & TSP & $\mathrm{Ca}$ & $\mathrm{Mg}$ & $\mathrm{Cl}$ \\
\hline Alkalinity & $\begin{array}{l}0.568 \\
0.0009\end{array}$ & & & & & & & & & \\
\hline \multirow[t]{2}{*}{ Conductance } & 0.577 & 0.830 & & & & & & & & \\
\hline & 0.008 & $<0.001$ & & & & & & & & \\
\hline \multirow[t]{2}{*}{ TDS } & 0.577 & 0.829 & 1.000 & & & & & & & \\
\hline & 0.008 & $<.001$ & 0 & & & & & & & \\
\hline \multirow[t]{2}{*}{ K } & 0.459 & 0.796 & 0.951 & 0.951 & & & & & & \\
\hline & 0.042 & $<0.001$ & $<0.001$ & $<0.001$ & & & & & & \\
\hline \multirow[t]{2}{*}{$\mathrm{Na}$} & 0.533 & 0.728 & 0.940 & 0.940 & 0.938 & & & & & \\
\hline & 0.016 & $<0.001$ & $<0.001$ & $<0.001$ & $<0.001$ & & & & & \\
\hline \multirow[t]{2}{*}{ TSP } & 0.524 & 0.772 & 0.684 & 0.683 & 0.633 & 0.606 & & & & \\
\hline & 0.018 & $<0.001$ & 0.001 & 0.001 & 0.008 & 0.005 & & & & \\
\hline \multirow[t]{2}{*}{$\mathrm{Ca}$} & 0.621 & 0.859 & 0.834 & 0.834 & 0.733 & 0.632 & 0.693 & & & \\
\hline & 0.003 & $<0.001$ & $<0.001$ & $<0.001$ & $<0.001$ & 0.008 & 0.001 & & & \\
\hline \multirow[t]{2}{*}{$\mathrm{Mg}$} & 0.469 & 0.727 & 0.959 & 0.959 & 0.956 & 0.975 & 0.594 & 0.652 & & \\
\hline & 0.037 & $<0.001$ & $<0.001$ & $<0.001$ & $<0.001$ & $<0.001$ & 0.006 & 0.002 & & \\
\hline \multirow[t]{2}{*}{$\mathrm{Cl}$} & 0.586 & 0.783 & 0.992 & 0.992 & 0.933 & 0.939 & 0.647 & 0.804 & 0.962 & \\
\hline & 0.007 & $<0.001$ & $<0.001$ & $<0.001$ & $<0.001$ & $<0.001$ & 0.002 & $<0.001$ & $<0.001$ & \\
\hline \multirow[t]{2}{*}{$\mathrm{HCO}_{3}^{-}$} & 0.738 & 0.743 & 0.896 & 0.896 & 0.874 & 0.943 & 0.617 & 0.671 & 0.896 & 0.896 \\
\hline & $<0.001$ & $<0.001$ & $<0.001$ & $<0.001$ & $<0.001$ & $<0.001$ & 0.004 & $<0.001$ & $<0.001$ & $<0.001$ \\
\hline
\end{tabular}

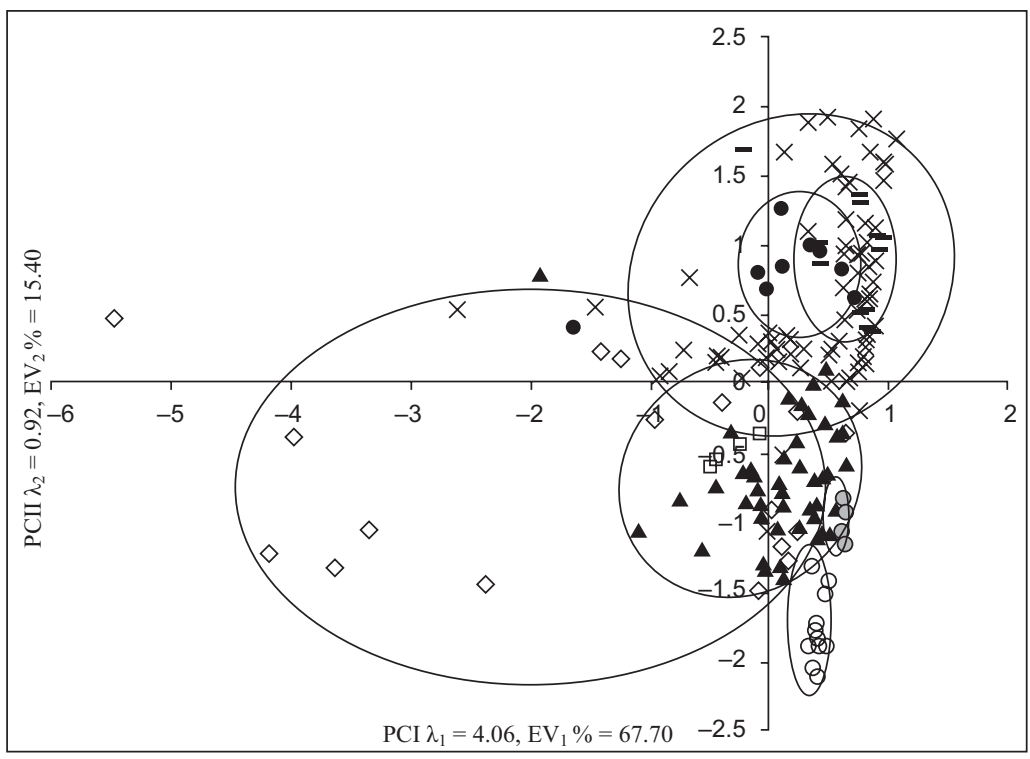

Fig. 4. Principal component analysis applied on different regions of the world. Regional differences are illustrated by clusters of points. $\diamond$ Pakistan (present study), $\boldsymbol{\Delta}$ India, $\square$ Romania, $\bigcirc$ Saudi Arabia, - Brazil, $\times$ China, - France, o Bangladesh 
Table VI. Parameters (from this study and reported for other regions of the world) on which principal component analysis was applied.

\begin{tabular}{|c|c|c|c|c|c|c|}
\hline $\mathrm{pH}$ & $\mathrm{Na} / \mu \mathrm{eq} \mathrm{L}^{-1}$ & $\mathrm{~K} / \mu \mathrm{eq} \mathrm{L}^{-1}$ & $\mathrm{Ca} / \mu \mathrm{eq} \mathrm{L}^{-1}$ & $\mathrm{Mg} / \mu \mathrm{eq} \mathrm{L}^{-1}$ & $\mathrm{Cl} / \mu \mathrm{eq} \mathrm{L}^{-1}$ & References \\
\hline $5.55-8.09$ & $2.18-870.32$ & $1.28-248.15$ & $14.97-1626.75$ & \begin{tabular}{|ll}
5.76 & -1646.09
\end{tabular} & $0.03-6039.49$ & This study \\
\hline $4.00-5.10$ & $7.00-74.40$ & $1.80-27.60$ & $4.40-286.60$ & $0.6-18.5$ & $3.70-\quad 31.80$ & $\begin{array}{l}\text { Honorio et al., } \\
2012 .\end{array}$ \\
\hline 4.70 & 37.00 & 11.00 & 33.00 & 12.00 & 17.00 & $\begin{array}{l}\text { Fluesa et al., } \\
2002 .\end{array}$ \\
\hline $4.96-5.12$ & $1.60-7.20$ & $2.50-\quad 2.40$ & $3.50-7.90$ & $1.90-5.50$ & $4.20-$ & $\begin{array}{l}\text { Mello and } \\
\text { Almeida, } 2004 .\end{array}$ \\
\hline $4.40-4.50$ & $2.30-4.50$ & $2.50-\quad 3.50$ & $2.30-7.70$ & $1.20-2.30$ & $4.90-$ & $\begin{array}{l}\text { Lara et al., } \\
2001 .\end{array}$ \\
\hline $6.50-6.73$ & $8.45-17.34$ & $2.42-\quad 4.23$ & $14.92-23.70$ & $4.44-8.05$ & $9.90-$ & $\begin{array}{l}\text { Khare et al., } \\
2004 .\end{array}$ \\
\hline $5.50-6.30$ & $11.0-28.9$ & $2.20-\quad 3.40$ & $15.10-36.90$ & $4.90-10.60$ & $11.40-\quad 30.90$ & Das et al., 2005. \\
\hline $5.49-7.00$ & $4.80-95.70$ & $2.10-117.20$ & $9.00-368.00$ & $1.70-60.00$ & $4.20-491.80$ & $\begin{array}{l}\text { Kulshrestha et } \\
\text { al., } 2003 \text {. }\end{array}$ \\
\hline $5.70-6.50$ & $1.30-97.20$ & $1.10-10.20$ & $7.50-41.50$ & $0.80-24.50$ & $2.20-113.40$ & $\begin{array}{l}\text { Parashari et al., } \\
2001 .\end{array}$ \\
\hline $5.77-6.62$ & $17.79-29.48$ & $9.67-22.66$ & $38.24-116.34$ & $13.26-30.50$ & $24.81-$ & $\begin{array}{l}\text { Tiwari et al., } \\
2007 .\end{array}$ \\
\hline $6.30-7.10$ & $7.10-17.90$ & $8.60-10.50$ & $25.00-70.30$ & $4.00-24.10$ & $9.60-\quad 23.40$ & Jain et al., 2000. \\
\hline $3.55-6.83$ & $0.87-7.39$ & $1.54-44.10$ & $18.80-163.80$ & $4.53-47.30$ & $0.85-128.10$ & $\begin{array}{l}\text { Han and Liu, } \\
2006 .\end{array}$ \\
\hline $3.71-5.82$ & $0.18-11.23$ & $0.40-58.58$ & $17.34-1568.73$ & $2.62-97.91$ & $1.39-$ & $\begin{array}{l}\text { Wang and Han, } \\
2011 .\end{array}$ \\
\hline $4.33-4.90$ & $8.34-15.80$ & $1.10-\quad 2.27$ & $21.40-54.40$ & $2.21-5.05$ & $18.40-$ & $\begin{array}{l}\text { Huang et al., } \\
2012 .\end{array}$ \\
\hline $6.06-6.38$ & $41.97-72.43$ & $17.64-23.56$ & $107.56-147.75$ & $17.90-25.19$ & $40.90-$ & $\begin{array}{l}\text { Arsenea et al., } \\
2007 .\end{array}$ \\
\hline $4.40-5.70$ & $15.00-70.00$ & $4.00-83.00$ & $5.00-166.00$ & $6.00-19.00$ & $17.00-167.00$ & $\begin{array}{l}\text { Sanusi et al., } \\
1996 .\end{array}$ \\
\hline $6.94-7.78$ & $2.55-11.46$ & $0.65-\quad 2.15$ & $28.8-87.0$ & $0.77-2.86$ & $4.39-$ & $\begin{array}{l}\text { Alabdula'aly } \\
\text { and Khan, } 2000 .\end{array}$ \\
\hline $6.40-6.74$ & $0.18-\quad 1.70$ & $0.04-\quad 0.37$ & $0.42-\quad 1.30$ & $0.04-0.19$ & $37.23-107.42$ & $\begin{array}{l}\text { Hadi et al., } \\
1999 .\end{array}$ \\
\hline
\end{tabular}

conductivity, alkalinity, TDS and $\mathrm{HCO}_{3}^{-}$(Table VII). The second component (PC-2) $(15.40 \%$ of the variance) was a function of $\mathrm{pH}$, alkalinity, $\mathrm{Ca}^{2+}$, $\mathrm{Mg}^{2+}$, and TSP.

Samples of different regions of the world were grouped based on the chemical composition of rainwater (Fig. 4). The samples of different parts of China were similar in composition with each other and with samples from France and Brazil, also showing similarity in level and source of pollution. 
Table VII. Component matrix of compositional parameters (significant principal components are shown in bold characters).

\begin{tabular}{|c|c|c|}
\hline Variable & PC-1 & PC-2 \\
\hline $\mathrm{pH}$ & -0.22 & -0.54 \\
\hline $\mathrm{Na}^{+} / \mathrm{mg} \mathrm{L}^{-1}$ & -0.315 & 0.293 \\
\hline $\mathrm{K}^{+} / \mathrm{mg} \mathrm{L}^{-1}$ & -0.318 & 0.244 \\
\hline $\mathrm{Ca}^{2+} / \mathrm{mg} \mathrm{L}^{-1}$ & -0.282 & -0.37 \\
\hline $\mathrm{Mg}^{2+} / \mathrm{mg} \mathrm{L}^{-1}$ & -0.315 & 0.34 \\
\hline $\mathrm{Cl}^{-} / \mathrm{mg} \mathrm{L}^{-1}$ & -0.327 & 0.142 \\
\hline Alkalinity / $\mathrm{mg} \mathrm{CaCO}_{3} \mathrm{~L}^{-1}$ & -0.293 & -0.284 \\
\hline Conductivity / mS & -0.331 & 0.107 \\
\hline $\mathrm{TDS} / \mathrm{mg} \mathrm{L}^{-1}$ & -0.331 & 0.108 \\
\hline$\left[\mathrm{HCO}_{3}\right] / \mathrm{mg} \mathrm{L}^{-1}$ & -0.313 & 0.059 \\
\hline $\mathrm{TSP} / \mathrm{mg} \mathrm{L}^{-1}$ & -0.25 & -0.428 \\
\hline
\end{tabular}

The rain samples from Bangladesh matched with the precipitation samples from India. Some Pakistani samples (except those of highly polluted gales) also matched with data of India due to the same geological and climatic conditions.
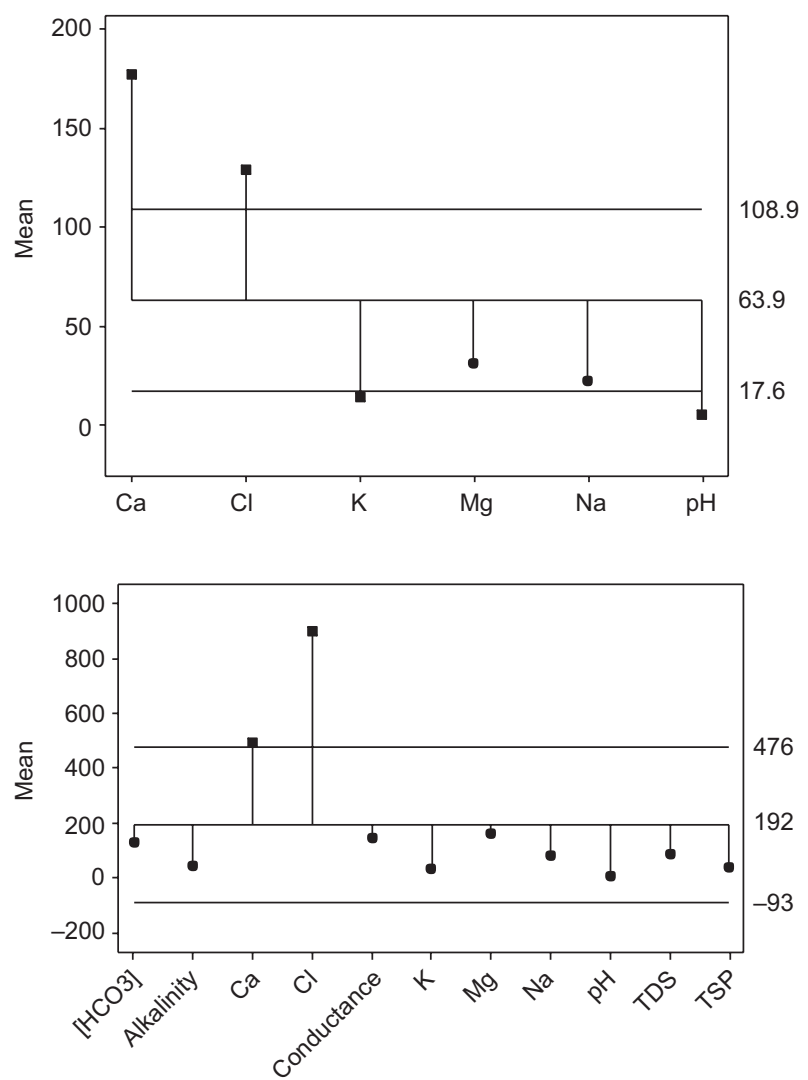

Fig. 5. One-way normal analysis of means (ANOM) applied on (a) data of other arid and tropical regions of the world, and (b) the present study.
Scattered separation is due to the variation in parameters during the same monsoon season. Saudi Arabia is grouped separately, showing a climatic difference as a result of different sources of pollution. Therefore, it is concluded that PCA is a good statistical tool for the source identification and level of air pollution in rainwater samples.

One-way normal analysis of means (ANOM) was applied to the data reported for this study and other regions of the world (Table VI). The patterns of Figures $5 \mathrm{a}$ and $\mathrm{b}$ are closely similar, showing that $\mathrm{Ca}^{2+}$ and $\mathrm{Cl}^{-}$are the most significant discriminating parameters accountable for variations in level and source of pollution (from natural or anthropogenic origin). No significant variation $(\mathrm{p}<0.05)$ was observed in other properties of rain samples.

\section{Conclusions}

The observed average of rainwater $\mathrm{pH}$ was 5.81 and 7.16 for UR and BZ samples, respectively. No acidic rain event was detected, which denotes limited influence of industrial activities. The high amounts of $\mathrm{Ca}^{2+}$ and TSP in BZ samples shows the dominancy of particulate matters of alkaline nature, like dust particles. Higher concentrations of pollutants in the first gale suggested that the dry season scavenges most of the pollutants from the atmosphere. Based on the results of the present study, it can be said that rainwater is safe for drinking, as none of the samples exceeded the maximum contaminant limits for drinking water. The Pakistan Environmental Protection Agency should enact laws for the proper handling of construction and demolition materials from open sites and promote initiatives for their strict implementation. The concerned authorities should monitor air pollution on a continuous basis considering rainwater as a potential indicator for environmental assessment.

\section{References}

Alabdula'aly A.I. and M. A. Khan,2000. Chemistry of rain water in Riyadh, Saudi Arabia, Arch. Environ. Contam. Toxicol. 39, 66-73.

APHA, AWWA and WEF, 1992. Standard methods for examination of water and wastewater. 18th ed. American Public Health Association, Washington, DC 20005.

Arsenea C., R. I. Olariua and N. Mihalopoulos, 2007. Chemical composition of rainwater in the northeastern Romania, Iasi region (2003-2006), Atmos. Environ. 41, 9452-9467. 
Das R., S. N. Das and V. N. Misra, 2005. Chemical composition of rainwater and dustfall at Bhubaneswar in the east coast of India, Atmos. Environ. 39, 5908-5916.

Dupre B., Ph. Negrel, F. Seimbille and C. J. Allegre, 1994. ${ }^{87} \mathrm{Sr} /{ }^{86} \mathrm{Sr}$ ratios variation during a rain event, Atmos. Environ. 28, 617-620.

Fluesa M., P. Hamaa, M. J. L. Lemesa, E. S. K. Dantasa and A. Fornaro, 2002. Evaluation of the rainwater acidity of a rural region due to a coal-fired power plant in Brazil, Atmos. Environ. 36, 2397-2404.

Ghauri M., Salam, and M. I. Mirza, 1994. An assessment of air quality in Karachi, Pakistan, Environ. Monit. Assess. 32, 37-45.

Hadi D.A., M. Billah, K. F. Biswas and I. Rafiqul, 1999. A study on chemical composition of atmospheric precipitation at Savar, Joydevpur, Tongi and Naryanganj, Bangladesh, Water, Air, Soil Poll. 111, 377-384.

Ham Y. S., H. Kobori, J. H. Kang and J. H. Kim, 2010. Ammonium nitrogen deposition as a dominant source of nitrogen in a forested watershed experiencing acid rain in central Japan, Water, Air, Soil Poll. 212, 337-344.

Hameed A., M. J. Al Obaidy and J. Himanshu, 2006. Chemical composition of rainwater in a tropical urban area of northern India, Atmos. Environ. 40, 6886-6891.

Han G. and C. Q. Liu, 2006. Strontium isotope and major ion chemistry of the rainwater from Guiyang, Guizhou Province, China, Sci. Total Environ. 364, 165-174.

Holder C.D., 2004. Rainfall interception and fog precipitation in a tropical montane cloud forest of Guatemala, Forest Ecol. Manag. 190, 373-384.

Honorio B. A. D., A. M. C. Horbe and P. Seyler, 2012. Chemical composition of rainwater in western Amazonia-Brazil, Atmos. Res. 98, 416-425.

Huang K., G. Zhuang, C. Xu, Y. Wang and A. Tang, 2008. The chemistry of the severe acidic precipitation in Shanghai, China, Atmos. Res. 89, 149-160.

Huang X.F., X. Li, L. Y. He, N. Feng, M. Hub, Y. W. Niu and L. W. Zeng, 2012. Study of rainwater chemistry in a coastal mega-city in South China, Atmos. Res. 97, 185-193.

Huo M., Q. Sun, Y. Bai, P. Xie, Z. Liu, X. Wang and J. Li, 2011. Acidic and basic properties and buffer capacity of airborne particulate matter in an urban area of Beijing, Environ. Monit. Assess. 176, 355-364.

Institutional Analysis of Air Quality Management in Urban Pakistan. 2009. Draft Report. http://cleanairinitiative. org/portal/system/files/attach/AQM_Draft_Final_Report.pdf. (accessed on August 25, 2013).
Jain M., U. C. Kulshrestha, A. K. Sarkar and D. C. Parashar, 2000. Influence of crustal aerosols on wet deposition at urban and rural sites in India, Atmos. Environ. 34, 5129-5137.

Kaiser H.F., 1960. The application of electronic computers to factor analysis, Educ. Psycho. Meas. 20, 141-151.

Khare P., A. Goel, D. Patel and J. Behari, 2004. Chemical characterization of rainwater at a developing urban habitat of Northern India, Atmos. Res. 69, 135-145.

Khemani L.T., G. A. Momin, P. S. P. Rao, A. G. Pillai, P. D. Safai, K. Mohan and M. G. Rao, 1994. Atmospheric pollutants and their influence on acidification of rainwater at an industrial location on the west coast of India, Atmos. Environ. 28, 3145-3154.

Kulshrestha U. C., Kulshrestha, R. S., Kulshrestha, G. S. R. Sastry and M. Vairamani, 2003. Chemical characteristics of rainwater at an urban site of south-central India, Atmos. Environ. 37, 3019-3026.

Lara L. B. L. S. , P. Artaxo, L. A. Martinelli, R. L. Victoria, P. B. Camargo, A. Krusche, G. P. Ayers, E. S. B. Ferraz and M. V. Ballester, 2001. Chemical composition of rainwater and anthropogenic influences in the Piracicaba River Basin, Southeast Brazil, Atmos. Environ. 35, 4937-4945.

Mello W.Z. and M. D. Almeida, 2004. Rainwater chemistry at the summit and southern flank of the Itatiaia massif, Southeastern Brazil, Environ. Pollut. 129, 63-68.

Mohiuddin K. M., H. M. Zakir, K. Otomo, S. Sharmin and N. Shikazono, 2010. Geochemical distribution of trace metal pollutants in water and sediments of downstream of an urban river, Int. J. Environ. Sci. Tech. 7, 17-28.

Parashari D.C., U. C. Kulshrestha and M. Jain, 2001. Precipitation and aerosol studies in India, Environ. Monit. Assess. 66, 47-61.

Ramírez Lara E., R. M. Guardiola, Y. G. Vásquez and I. B. Rentería, 2010. Chemical composition of rainwater in northeastern Mexico, Atmósfera 23, 213-224.

Sanusi A., H. Wortham, M. Millet and P. Mirabel, 1996. Chemical composition of rainwater in Eastern France, Atmos. Environ. 30, 59-71.

Satsangi G. S., A. Lakhani, P. Khare, S. P. Singh, K. M. Kumari and S. S. Srivastava, 1998. Composition of rainwater at semiarid rural site in India, Atmos. Environ. 32, 3783-3793.

Tiwari S., U. C. Kulshrestha and B. Padmanabhamurty, 2007. Monsoon rain chemistry and source apportionment using receptor modeling in and around National Capital Region (NCR) of Delhi, India, Atmos. Environ. 41, 5595-5604. 
Tuncel S. G. and S. Ungor, 1998. Rainwater chemistry in Ankara, Turkey, Atmos. Environ. 30, 2721-2722.

Versari A., G. P. Parpinello and S. Galassi, 2002. Chemometric survey of Italian bottled mineral waters by means of their labelled physicochemical and chemical composition, J. Food Compos. Anal. 15, 251-264.

Wahid A., E. Milne, S. R. A. Shamsi, M. R. Ashmore and F. M. Marshall, 2001. Effects of oxidants on soybean growth and Yield in the Pakistan Punjab, Environ. Pollut. 113, 271-280.

Wang H. and G. Han, 2011. Chemical composition of rainwater and anthropogenic influences in Chengdu, Southwest China, Atmos. Res. 99, 190-196.
WHO, 2006. Guidelines for Drinking-Water Quality, third edition, volume 1. Recommendations. World Health Organization, Geneva.

Wroble A., E. Rokita and W. Maenhaut, 2000. Transport of traffic-related aerosols in urban areas, Sci. Total Environ. 257, 199-211.

Xu Z. and G. Han, 2009. Chemical and strontium isotope characterization of rainwater in Beijing, China, Atmos. Environ. 43, 1954-1961.

Zapletal M., D. Kunak and P. Chroust, 2007. Chemical characterization of rain and fog water in the Cervenohorske Sedlo (Hruby Jesenik mountains, Czech Republic), Water Air Soil Pollut. 186, 85-96. 